\title{
Incorporating Reverse Supply Chain in the Poultry Process of Bangladesh
}

\author{
Mohammad Shamsuddoha \\ PhD Research Student \\ Graduate School of Business, Curtin University \\ E-mail: mdsdoha@gmail.com
}

\begin{abstract}
Manufacturing industries are using environment sustainability and reverse supply chain concepts to manage existing waste resources. Yet, significant number of industries failed to incorporate appropriate production process to do so. Bangladesh poultry industries are struggling to achieve environment sustainability due to inappropriate dealings of waste recycles and reuse. This is why, researcher has chosen this area based on particular case industry to observe whether proper supply chain process can protect and improve the environment. The objectives of this paper are twofold. First, it offers a literature review on environment sustainability and RSC issues. Second, it develops input-output process model for environmental sustainability. Quantitative, design science and case study methods used in this study. Outcome of this research demonstrated the way of achieving environmental sustainability by utilizing wastes.
\end{abstract}

Keywords: Environmental Sustainability, Reverse Supply Chain, Poultry, Bangladesh

\section{Introduction}

Poultry industry in Bangladesh is a significant contributor to generate cheap sources of high quality meat, optimum nutrition value and generating employment. This industry failed to adopt latest technology and concepts for poultry waste management to protect land, air and water pollution. Industries are now under tremendous pressure by the conscious citizens and environmentalist groups to incorporate environment friendly process in their operation. In this situation, it is timely and important to incorporate appropriate environmental concept in their supply chain operation. Reverse supply chain concept is the appropriate concept like $3 \mathrm{R}$ that will turn into environment hazard free process by doing proper waste management. Such kind of waste management might have economic, social and environmental viability for the concern society. The focal point of this current research is to include reverse supply chain knowledge within the existing process so that it can perform environmental protection in a cost-effective and profitable manner.

\section{Literature}

Environmental problems of land, water and air pollution occurs by livestock sector (Steinfeld et al. 2006). Manufacturing process hinders environment throughout different stages of production (Corbett \& Kleindorfer, 2003; Seuring \& Muller, 2008). Bangladesh poultry livestock sub-sector is not exception from the same blame of damaging environment. Huge volume of livestock wastes dumps in such places, which is the main causes for above pollution. Waste management in agriculture is getting importance as waste can make additional resources for valuable by-products. In this situation, proper supply chain process 
are needed to optimize resources utilization (Boyazoglu, 2002). Perhaps, it is evident from literature that this sub-sector plays a crucial role in economic growth and employment generation (Shamsuddoha \& Sohel, 2008).

On the other hand, sustainability denotes meeting the present needs without hampering future requirements (WCED, 1987). It also focuses on ecological issues in conjunction with implicit recognition of social and economic issues (Jennings, 1995). Mill highlights unfettered expansion over environment (Mill, 1848). Interestingly, Ricardo suspected that scientific progress would postpone the time when population would overtake resources (Ricardo, 1973). Daly also arisen a question regarding the wisdom of infinite throughput growth on a finite earth (Daly, 1999). "The Limits to Growth" (Meadows, Meadows, Randers, \& Behrens, 1972) and "Beyond the Limits" (Meadows, Meadows, \& Randers, 1992) quake the passion of the technological optimists. For this, industries need to be careful in using and dumping internal or external resources. They need to find out a way to utilize resources before dump it out as resource is limited.

Recently, supply chain deals by-products manufacturing from wastes or recycle products, extend and recovery processes of product end-of-life (Linton, Klassen, \& Jayaraman, 2007). Once more, reverse supply chain is relatively new concept to deal product return, recycle, reuse to keep intact of environment by using industry wastes (Shamsuddoha, 2011a). Agriculture based society are facing challenges to implement environmental sustainability and appropriate supply chain concepts in their operation (Lal, 1991; Sands \& Podmorea, 2000; Shamsuddoha, 2010). Accordingly, integrated sustainability, supply chain and poultry process have received little attention in the research arena. Hence, this paper has taken account of such research gap that related to Bangladesh poultry process along with sustainability, supply chain and environmental issues.

\section{Why did Bangladesh Poultry?}

Bangladesh is densely populated countries with limited land and water resources. Over 73\% of the total population lives in the rural areas and highly dependent on agricultural system. The contribution of the livestock sub-sector to GDP currently 3.2\% (Jari Collin, Eero Eloranta, \& Jan Holmstrom, 2009). Poultry industry is one of the major among livestock subsector that committed to supply cheap sources of good quality nutritious animal protein to the nation (Shamsuddoha, 2010). Approximately, 20\% of the protein consumption originates from poultry meat. Poultry farms have grown up under private ownership having inadequate knowledge on reverse supply chain and ecological sustainability (Shamsuddoha, 2011b). Of late, young generation are motivated to take it as main profession due to high competition in the job market. These young educated people are trying best to accept new technologies and concepts in their farming operation. Applications of such dynamic concepts easily guide them toward scientific farming with better profitability and sustainability. Insignificant numbers of related research done by the academicians. This kind of research can fill the gap of knowledge, which will help the farmers to implement sustainability and RSC within their operations. It also help to achieve environmental and social success for the society and industry (Shamsuddoha, 2010). Such kind of gap aggravated the researcher to undertake current research on this particular field. 


\section{Methodology}

The study covered literature review on environmental sustainability along with reverse supply chains. This paper used observation tool to build up simulation poultry model considering reverse supply chain issue. Both primary and secondary information have used in this study. Primary information collected in February 2011, mainly through in-depth interviews (90 minutes long) with the sample respondents. The total respondents were three executives from case poultry industry in Bangladesh. These respondents nominated based on their reputation in related knowledge and experiences. Secondary information collected from referral journals and conference papers, statistical yearbooks and various reports. This study followed research paradigm of positivist ontology, empirical epistemology and quantitative methodology based on case study of real poultry process. A Case study is observing the descriptions of particular instance of an event (Yin 1994). Again, design science methodology has chosen for this study. Design science is concerned with develop and evaluate an artifact of a model (March \& Smith, 1995; Simon, 1969). Here, an artifact means design and develop objects that can meet specific goal (Venable, 2006a, 2006b). Historic data from case industry used to design the artefacts' of the model to view as close as realistic environment. For developing simulation poultry model, SIMUL8 package has used to draw and design existing poultry processes in order to investigate the research objectives.

\section{Reverse Supply Chain and Poultry Wastes}

Reverse supply chain clearly addressing the issues of disposal, recycling, reconditioning and remanufacturing (Kocabasoglu, Prahinski, \& Klassen, 2007). It also refers the series of activities necessary to retrieve a product, either dispose or recover value (Guide \& Van, 2002; Prahinski \& Kocabasoglu, 2006). Yet again, RSC potentially can reduce negative environmental impacts by extracting virgin raw materials and waste disposal (Kocabasoglu et al., 2007). Most reverse supply chains are organized to carry out five key processes of product acquisition, reverse logistics, inspection and disposition, remanufacturing or refurbishment and marketing (Blackburn, Guide, Wassenhove, \& Souza, 2004). Reverse logisticss has different characteristics of environmentally conscious manufacturing, including disassembly, reuse (Edwards \& Daniel, 1992), recycling and remanufacturing (Gungor \& Gupta, 1999). There are various poultry wastes: litter (Burak Aksoy, Harry T. Cullinan, Norman E. Sammons Jr, \& Mario R. Edenb, 2008; Rivera-Cruz et al., 2008), feathers (Shih, 1993), broken eggs and intestines (Burns \& Stickney, 1980). These mentioned wastes can use to recycle, reuse to generate valuable by-products. For example, poultry litter can be the source of fertilizer (Gupta \& Charles, 1999), bio gas (Bala, 1991), charcoal and fish feed (Burns \& Stickney, 1980); feathers can be raw materials for the Bed industry (Shamsuddoha, 2011a), broken eggs for the bakery and intestines for the fish farms (Shamsuddoha, 2011a). All these areas have great potential to meet social, economic and environmental aspects that will make the industry and society more sustainable.

\section{Environment Sustainability along with Reverse Supply Chain}

Bangladesh poultry industry does not maintain structured sustainable operation based on triple bottom line of social, economic and environment. Survival, resilience and efficiency is described as environmental, economic and social factors that underpin sustainability (Peacocka \& Shermanb, 2010). Sustainability must implement with the existing farm operation to attain actual sustainable growth in their production and operation. To achieve 
three factor successes in the poultry industry in Bangladesh, the researcher focused on the total poultry operation and split up into three phases. These three phases named as mainstream, forward and reverse supply chain. Internationally, there are numerous large companies applying reverse supply chain concepts for the sake of the environment, customer satisfaction, additional profit and so forth. These kinds of practices are not always non-profit oriented. In other words, there can be a profit motive to occupy reverse supply chain solutions. There are small chances of product retrieval, return or reconditioning, as most poultry products are perishable. However, there are immense opportunities to reuse or recycle poultry wastage. By reusing poultry wastage, industries can make valuable products like fertilizers, biogas, pillows, charcoal, and bakery items. This kind of wastage conversion will help to maintain sustainable environment (Shamsuddoha, 2011a). Until now, sustainability, Environment and RSC have not received proper attention by the poultry stakeholders.

\section{Simulation Model for Environmental Sustainability through RSC}

This research develops an input-output poultry process model by conducting in-depth interviews with farm executives. It also observed that Bangladesh poultry industries are not using their wastes properly. As a result, lack of poultry waste usage pollutes environment. Few poultry industries are trying some environmental practices which help them to remain free from common poultry disease and make extra economic benefits by creating valuable by-products from wastes (Shamsuddoha, 2011a). Appropriate poultry waste management can help to alleviate environmental hazards. The economic and social aspects of RSC with respect to poultry industry are incredibly vivid in the model. RSC process applied to each individual waste. It helps to build a new small or medium type business. These businesses can easily commercialize their products for both home and small industrial users in Bangladesh.

The model has developed based on poultry process in Bangladesh. This model has conceptually developed through in depth interview with poultry executives and entrepreneurs. RSC part of this model has developed based on real and potential to use poultry wastes. Poultry wastes can be vital resources for Bangladesh people. Such resources can make various valuable by-products that will fulfil the needs of power, fertilizers, fish feed and bakery stuff. This process will help environment restoration in concerned society. Thus, the proper use of RSC can further contribute to other types of industry by providing raw materials. This research shows the way of achieving environmental sustainability using reverse supply chain within the mainstream poultry process. It is now visible through the model that poultry wastes can well managed by applying RSC.

Figure one exhibits the poultry model has fitted in simulation environment of Simul8 package. This model is containing three different parts of mainstream, forward and reverse supply chain. Mainstream part is containing general supply chain of poultry industry that started from parent (mother of chicks) and ends up with finished product of meat and eggs. Second, forward supply chain of this simulation model consist of distributor, farmers, middlemen of mature bird etc. This is the area where employment and other socio-economic benefits seen based on the volume of bird transacted or reared. On the other hand, RSC part consists of managing poultry wastes of broken and un-hatched eggs, poultry litter, poultry feather etc. This particular section highlights areas in this research. This research reveals how poultry wastes could be input of other by-product industry or additional economic potential for the existing industry. 


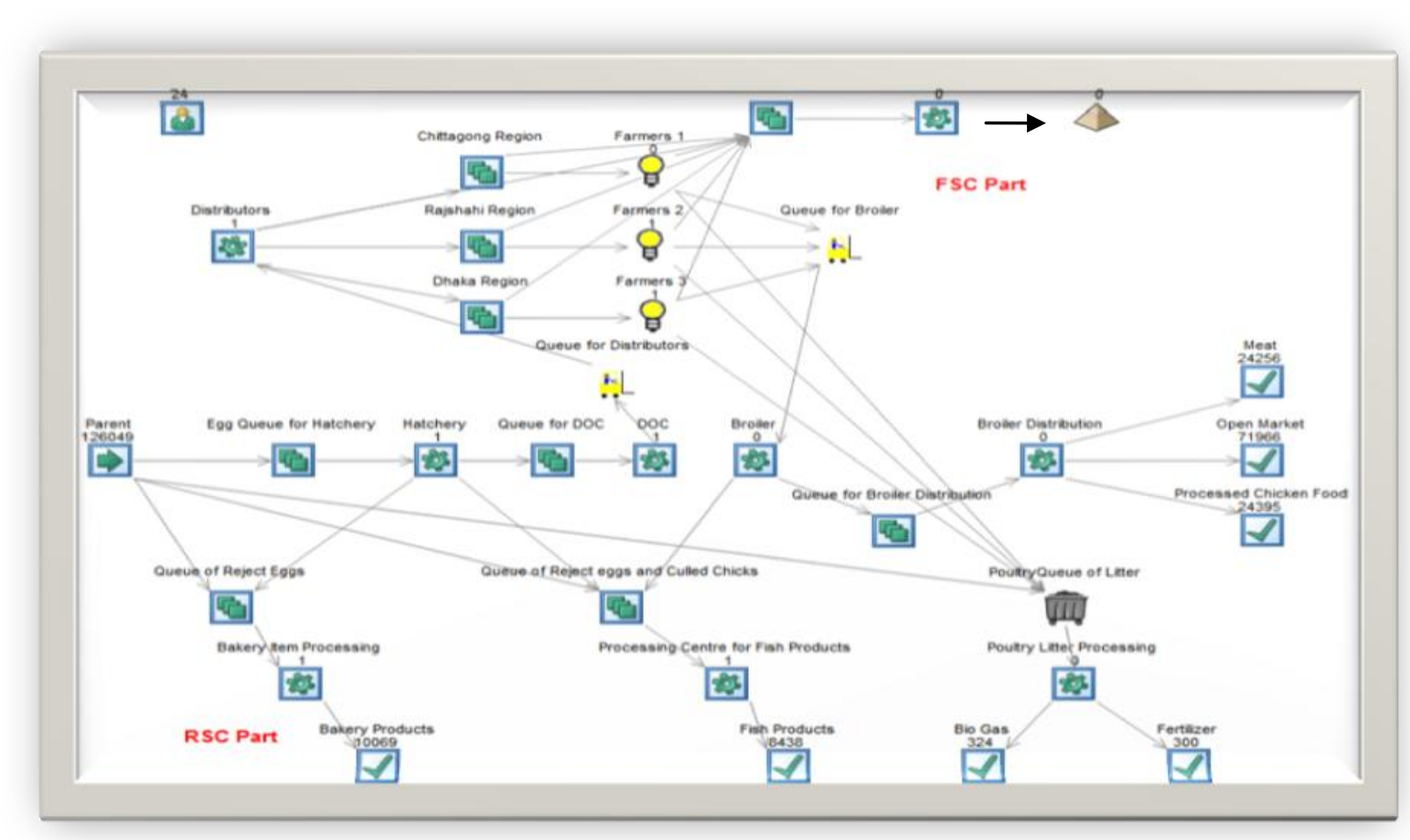

Fig One: Poultry Simulation Model along with RSC Application

Poultry industry generates lots of poultry waste such as culled birds; rejected hatching eggs; litter; manure; rejected, damaged, broken and un-hatched eggs; waste feed, poultry intestines and feathers (Shamsuddoha, 2011a). Poultry industries may use of RSC concept to manage wastes. Such as, bio-gas, fertilizers, artificial charcoal can be made from poultry litter, pillow and bed from feathers, fish feed from intestines and rejected eggs and feeds, bakery products from rejected eggs (Shamsuddoha, 2011a). By using this simulation model, industry personnel can easily figure out the volume of waste based on its input. They can simulate the figure as their own need. This model will figure out volume of final output of eggs and meat, employment, wastes, by-products, based on its input. Here, the researcher run the model based on historic data from case industry. The simulated result shows in the table (appendix) with three different random run of the model. A result shows the KPI of different artefact of the model, which defined as work centre, storage and work complete. It also shows the variation figures that come from various random run. These changes are the key for the decision makers to take the right decision.

\section{Further Direction and Conclusions}

In conclusion, the concept of the reverse supply chain relates to this poultry process model to protect environment and achieve sustainability. It is essential for the farmers and stakeholders to protect their environment for the sake of society and themself. Moreover, this process will not only utilizes poultry wastes but also keep our environment intact for the future generation. Furthermore, enhanced clean environment resulting from the implementation of the RSC concept will assist farmers to prevent common poultry diseases. Importantly, poultry entrepreneur can use this model to see projective input, output, queue time, deviation, efficiency, required resources, and finance and so on. The study initially investigates small number of historic data from the case industry. Future research could test the entire process model to find out exact details of the total industry operation and its optimality. This model developed based on three aspects of social, economic and environment. Further research can be done partially basis as well. 
Appendix

\begin{tabular}{|c|c|c|c|c|c|c|c|}
\hline $\begin{array}{c}\text { Simulation } \\
\text { Object }\end{array}$ & $\begin{array}{c}\text { Performance } \\
\text { Measure } \\
\end{array}$ & Run 1 & 2 & 3 & $-95 \%$ & $\begin{array}{c}\text { Avera } \\
\text { ge }\end{array}$ & $95 \%$ \\
\hline Parent & Number Entered & 126049 & 125854 & 12594 & 12587 & 12597 & 126086 \\
\hline \multirow{2}{*}{$\begin{array}{l}\text { Bakery } \\
\text { Processing }\end{array}$} & Average use & 0.99901 & 0.9990 & 0.9990 & 0.9990 & 0.9990 & 0.9990 \\
\hline & Completed Jobs & 10071 & 10106 & 10116 & 10050. & 10083 & 10116 \\
\hline \multirow{2}{*}{$\begin{array}{l}\text { Processing } \\
\text { Fish } \\
\text { Products }\end{array}$} & Average use & 0.99901 & 0.9990 & 0.9990 & 0.9990 & 0.9990 & 0.9990 \\
\hline & Jobs Completed & 8440 & 8397 & 8370 & 8363.9 & 8399.8 & 8435.6 \\
\hline \multirow{2}{*}{$\begin{array}{l}\text { Litter } \\
\text { Processing } \\
\end{array}$} & Average use & 09127 & 0.1061 & 0.0912 & 0.0808 & 0.094 & 0.108 \\
\hline & Jobs Completed & 624 & 648 & 614 & 612.22 & 628 & 643.77 \\
\hline \multirow{2}{*}{$\begin{array}{l}\text { Fish } \\
\text { Products }\end{array}$} & Number Col & 8438 & 8396 & 8368 & 8362.6 & 8398.4 & 8434.1 \\
\hline & St Dev & 1355.03 & 1359.2 & 1357.8 & 1353.9 & 1356.6 & 1359.3 \\
\hline \multirow[t]{2}{*}{ Fertilizer } & Number Complete & 300 & 305 & 297 & 291.89 & 300.2 & 308.50 \\
\hline & St Dev & 2.49184 & 2.6616 & 2.5724 & 2.4378 & 2.5455 & 2.6533 \\
\hline \multirow[t]{2}{*}{ Bio Gas } & Number Completed & 324 & 343 & 317 & 315.34 & 327.8 & 340.25 \\
\hline & St Dev & 2.51251 & 2.5374 & 2.4660 & 2.4755 & 2.5112 & 2.5469 \\
\hline
\end{tabular}

\section{REFERENCES}

Bala, B. K. (1991). System dynamics modelling and simulation of biogas production systems. Renewable energy, 1(5-6), 723.

Blackburn, J., Guide, D. V. R., Wassenhove, L. N. V., \& Souza, G. C. (2004). Reverse supply chains for commercial returns. California Management Review, 46(2), 1-20.

Boyazoglu, J. (2002). Livestock research and environmental sustainability with special reference to the Mediterranean basin. Small Ruminant Research, 45, 193-200.

Burak Aksoy, Harry T. Cullinan, Norman E. Sammons Jr, \& Mario R. Edenb. (2008). Poultry Litter Biorefinery Location in Alabama Through Minimization of Feedstock Transportation Cost. Environmental Progress, 27(4).

Burns, P. R., \& Stickney, R. R. (1980). Growth of Tilapia aurea in ponds receiving poultry wastes. Aquaculture, 20(2), 117-121.

Corbett, C. J., \& Kleindorfer, P. R. (2003). Environmental management and operations management: introduction to the third special issue. Production and Operations Management, 12(3), 287-289.

Daly, H. (1999). Steady State Economics (2nd ed.). Washington DC: Island Press.

Edwards, D. R., \& Daniel, T. C. (1992). Environmental Impacts of On-Farm Poultry Waste Disposal A Review. Bioresource Technology, 41 9-33.

Guide, J. V. D. R., \& Van, L. N. W. (2002). The reverse supply chain. Harvard Business Review, 80(2), 25-26.

Gungor, A., \& Gupta, S. M. (1999). Issues in Environmentally Conscious Manufacturing and Product Recovery: A Survey. Computers and Industrial Engineering, 36(4), 811-853.

Gupta, G., \& Charles, S. (1999). Trace elements in soils fertilized with poultry litter. Poultry Science, 78, 1695-1698.

Jari Collin, Eero Eloranta, \& Jan Holmstrom. (2009). How to design the right supply chains for your customers. 14.

Jennings, P. D. (1995). Ecologically sustainable organizations: an institutional approach. The Academy of Management review, 20(4), 1015-1052. 
Kocabasoglu, C., Prahinski, C., \& Klassen, R. D. (2007). Linking forward and reverse supply chain investments: the role of business uncertainty. Journal of Operations Management, 25, 1141-1160.

Lal, R. (1991). Soil structure and sustainability. Journal of Sustainable Agriculture, 1(4), 6791.

Linton, J. D., Klassen, R., \& Jayaraman, V. (2007). Sustainable supply chains: An introduction. Journal of Operations Management, 25(6), 1075-1082.

March, S., \& Smith, G. (1995). Design and Natural Science Research on Information Technology. Decision Support Systems, 15, 251-266.

Meadows, D., Meadows, D., \& Randers, J. (1992). Beyond the Limits: Global Collapse or a Sustainable Future. Post Mills, VT: Chelsea Green.

Meadows, D., Meadows, D., Randers, J., \& Behrens, W. (1972). The Limits to Growth. New York: Universe.

Mill, J. S. (1848). Principles of Political Economy (Vol. 2). New York: Collier.

Peacocka, C., \& Shermanb, D. M. (2010). Sustainable goat production: Some global perspectives. Small Ruminant Research(89), 70-80.

Prahinski, C., \& Kocabasoglu, C. (2006). Empirical research opportunities in reverse supply chains. Omega: The International Journal of Management Science, 34(6), 519-532.

Ricardo, D. (1973). Principles of Political Economy and Taxation (2nd ed.). London: Dent.

Rivera-Cruz, M. a. d. C., Narcı'a, A. T., Ballona, G. C. r., Kohler, J., Caravaca, F., \& Rolda'n, A. (2008). Poultry manure and banana waste are effective biofertilizer carriers for promoting plant growth and soil sustainability in banana crops. Soil Biology \& Biochemistry, 40 3092-3095.

Sands, G. R., \& Podmorea, T. H. (2000). A generalized environmental sustainability index for agricultural systems. Agriculture, Ecosystems and Environment, 79, 29-41.

Seuring, S., \& Muller, M. (2008). From a literature review to a conceptual framework for sustainable supply chain management. Journal of cleaner production, 16(15), 16991710.

Shamsuddoha, M. (2010). A sustainable supply chain process model for Bangladeshi poultry industry, Doctoral Students Colloquium 2010 (Vol. 1). Perth, Australia: Curtin Business School.

Shamsuddoha, M. (2011a). Applying reverse supply chain in the poultry industry. In T. Jefferson, M. Shamsuddoha, \& E. Young (Eds.), Emerging Research Initiatives and Developments in Business: CGSB Research Forum 2011 (Vol. 1, pp. 159-167). Perth, Australia: Curtin University.

Shamsuddoha, M. (2011b). Reverse supply chain process as environmental sustainability in the poultry industry of Bangladesh. In J. Goodison (Ed.), Doctoral Colloquium 2011 (Vol. 1). Perth: Curtin Business School, Curtin University.

Shamsuddoha, M., \& Sohel, M. H. (2008). Poultry rearing - an alternative income generating activity for rural women development of Bangladesh. The Chittagong University Journal of Business Administration, Bangladesh, 20(1), 119-132.

Shih, J. C. H. (1993). Recent development in poultry waste digestion and feather utilization: a review. Poultry Science, 72(9), 1617-1620.

Simon, H. (1969). The sciences of the artificial. Cambridge: MIT Press.

Venable, J. R. (2006a). A Framework for Design Science Research Activities, Information Resource Management Association Conference. Washington, DC, USA.

Venable, J. R. (2006b). The Role of Theory and Theorising in Design Science Research. In A. Hevner \& S. Chatterjee (Eds.), 1st International Conference on Design Science (DESRIST). Claremont, California, USA. 
WCED. (1987). Our Common Future. New York: WCED (World Commission on Environment and Development). 